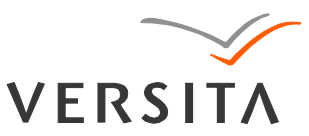

GEOCHRONOMETRIA 39(4) 2012: 285-294

DOI 10.2478/s13386-012-0017-1

Available online at

www.springerlink.com

\title{
GROWTH RESPONSES OF SESSILE OAK TO CLIMATE AND HYDROLOGICAL REGIME IN THE ZBYTKA NATURE RESERVE, CZECH REPUBLIC
}

\author{
ALŽBĚTA ČEJKOVÁ ${ }^{1,2}$ and SIMONA POLÁKOVÁ ${ }^{1,3}$ \\ ${ }^{1}$ University of South Bohemia in České Budějovice, Faculty of Science, \\ Branišovská 31, CZ-370 05, České Budějovice, Czech Republic \\ ${ }^{2}$ Administration of Orlické hory PLA, Dobrovského 332, CZ-516 01, Rychnov nad Kněžnou, Czech Republic \\ ${ }^{3}$ DAPHNE CR - Institute of applied ecology, Emy Destinnové 395, České Budějovice, Czech Republic
}

Received 23 November 2011

Accepted 16 July 2012

\begin{abstract}
Complex of Nature reservation Zbytka is the rest of various fen vegetation in the northeast part of the Czech Republic. It represents an important spring area which provides high quality potable water for more than 150000 inhabitants. Waterworks utilization was started in the 1960 s and the change of land-use practices has had a strong effect on the ecosystem. Oak chronology has been showing different tree growth trends since the start of the waterworks utilization. Also the occurrences of negative pointer years differ markedly before and after initiation of pumping underground water. Dendroclimatological analyses primarily revealed a close relationship between the temperature and tree growth - positive influence of spring and summer temperature. The period 1983-1992 of maximum artesian water pumping is expressed as higher tree-ring increments, but linear model analyses showed that the growth reaction of oak is not due to simple causality between temperature and underground water level. The radial increments reacted positively to the combination of high temperature during the vegetation season and low or, the contrary, high depth of underground water level. No direct relationship was detected between tree growth and fluctuation of underground water level; despite of the results dendrochronological data may be useful in historical ground water modelling studies. Results are also crucial for conflict of interests between nature preservation and potable water supply.
\end{abstract}

Keywords: dendrochronology; oak tree; water pumping; hydrology

\section{INTRODUCTION}

Complex of Nature reservation Zbytka is the rest of various fen vegetation in the northeast part of the Czech Republic. The reserve area is a valuable habitat of endangered species (e.g. Calamagrostis varia, Arabis nemorensis, Taraxacum mendax, Viola elatior, Carex hostiana, $C$.

Corresponding author: A. Čejková

e-mail: cejkova@gmail.com

ISSN 1897-1695 (online), 1733-8387 (print)

(C) 2012 Silesian University of Technology, Gliwice, Poland.

All rights reserved. lepidocarpa, Orchis militaris, Dactylorhiza incarnata, Allium angulosum, Ophioglossum vulgatum) and it is an object of botanist interest from the 1930s (e.g. Rohlena and Dostál, 1936; 1937-1938; Prokeš and Válek, 1944; 1946; Krčan and Kopecký, 1959; Kopecký, 1960; Krahulec, 1995; Hájek, 2009). For a long time, surroundings of Zbytka consist of agricultural landscape and therefore fens have been gradually changing by cultivation. Drained fens have been used as fertile cabbage fields, as 
well as pastures and meadows since the 19th century. During the 20th century, exploitation and drainage were continuing and non-exploited stands were reforested (Hájek, 2009).

The Zbytka nature reserve is a part of the spring area Litá - Mokré. Waterworks utilization was initiated in the 1960s and a progressive pumping started in 1978 (Hermann, 1995; Hrkal, 1998). The spring area has fundamental significance for the Hradec Králové region; it provides high-quality potable water for more than 150000 inhabitants (Růžička, 2006).

Changes in land-use practices have had an effect on ecosystem characteristics and it is related to climate and hydrology changes (Ford and Brooks, 2003; Dale, 1997). Alluvial forests are markedly influenced by the level of underground water and floods frequency. In wetlands, water can be both a limiting resource and a chronic stressor (Mitsch and Gosselink, 2007). Hydrology is a dominant driver of stand composition structure and growth, as well as tree architecture in wetland forests (Rodríguez-González et al., 2010). Effects of changes in hydrology regime vary among forest vegetation types, between young and mature stands and tree species (Becker et al., 1996). Attention has been usually paid to the effect of fluctuating hydrological condition (e.g. drainage, floods, pumping of water or dilution) on the growth of coniferous species, less on broadleaved species (Becker et al., 1996; Choi et al,. 2007; Dang and Lieffers, 1989; Freléchoux et al., 2000; Douda et al., 2009; Linderholm 1999; Linderholm and Leine 2004; Lageard and Drew 2008).

Our objective was to analyse the response of sessile oak trees to hydrological and climatic variations; specifically (1) to find out the role in fluctuations of the groundwater table caused by pumping on tree growth and (2) to investigate the relationship between tree growth and climate conditions influenced by specific site conditions. The results are crucial for conflict of interests between nature preservation and supply of potable water in the Hradec Králové region. Another important merit of this study was the application of tree-ring and hydrological records from Zbytka for the assessment of sustainability of the habitat. It will be subsequently useful for the development of strategies for conserving vulnerable fens and allow for better management of ground water resources.

\section{MATERIAL AND METHODS}

\section{Study site}

Zbytka reserve is a part of the spring area Litá Mokré in the northeast Bohemia (Fig. 1). It is situated near the left bank of Dědina stream on a flat alluvial plain (256-264 $\mathrm{m}$ a.s.1.) interlaced by drainage channels and depressions with intermittent streams (Hájek 2009).



Fig. 1. Map of study area - Zbytka nature reserve with boreholes $L t-1, L t-2, L t-6, V-2$ and monitoring $L t-5$. 
The Zbytka Nature Reserve was established for the purpose of protection of the fen ecosystem, intermittently wet Molinia meadows and oak-hornbeam forests on the area 79.42 ha in 1994 (Faltysová et al., 2002). This territory was included to the European Natura 2000 network by government provision $n .132 / 2005$.

The geological basement of the site is formed by mesozoic sedimentary bedrocks of Middle-Late Turonian Age - calcareous siltstone, calcareous clayey sandstone, marlstone and spongilit. The rigid bedrocks of Middle Turonian Age created artesian impervious strata of fissure aquifer (Hermann, 1995; Hrkal, 1998). Artesian water has neutral to weak alkaline reaction. The specific chemistry of water has caused fens character of wetlands and created quaternary freshwater limestone (Hrkal, 1998).

The average annual precipitation ranges from 550 to $600 \mathrm{~mm}$, the average yearly temperature is $8-9^{\circ} \mathrm{C}$, and the average monthly temperature is approximately -2 to $-3^{\circ} \mathrm{C}$ in January and 17 to $18^{\circ} \mathrm{C}$ in July (Tolasz et al., 2007).

\section{Waterworks utilization}

Plan of waterworks utilization of the spring area Litá - Mokré arose at the 1940s. The first dwell built sugar refinery from České Meziříčí and used it between 1962 and 1966 (Kroupa, 1986; Hájek, 2009). During the 1960s artesian boreholes Lt-1, Lt-2, V-2, Lt-5 and Lt-6 were made within the Nature reserve or near the boundaries. Lt-5 is a monitoring borehole from 1968; the others are pumping ones (Hájek, 2009).

Outlying boreholes Lt-01, Lt-02, V-1 have started operation in 1978-1979 (total uptake 50 1/s), but measurement of boreholes inside Zbytka area did not show any influence of underground water level. Boreholes Lt-6, Lt8 , and Lt-10 were joined in 1980, Lt-4 in 1983. Total sum of uptake between 1981 and 1983 reached 200 1/s and was reflected by water level fluctuation and subsidence with minimum 1982/1983 in Zbytka area. Accelerated pumping coincided with adjunction of the next boreholes Lt-1, Lt-2, V-2 (boreholes within the reserve or near the boundaries) in 1984 . The total sum of uptake exceeded 250 1/s with month maximum 340 1/s in April 1988. Massive decrease of water table was measured in 1984-1985 and 1990-1991. The decrease was intensified by precipitation deficit in 1983-1984 and 1989-1991, but during the period with higher precipitation in 1985-1988 the water table of the monitoring borehole fluctuated few meters below normal. The pumping has been reduced to $200 \mathrm{l} / \mathrm{s}$ in 1993. The water table in the monitoring borehole Lt-5 has been sustained at $257.5 \mathrm{~m}$ a.s.l. since 1997 (Hermann, 1995; Hrkal, 1998; Uhlík et al., 2006; Hájek, 2009).

The average level of water non-affected by pumping fluctuates between $258-259 \mathrm{~m}$ a.s.l. in the spring area. An assumption exists that pumping of artesian water has caused a reduction of waterlogging period in the situation above $257.5 \mathrm{~m}$ a.s.l. only to water full springtime and has caused desiccation above this level (Bušek 2006). Artesian water saturates southern fenny part of Zbytka where- as waterlogging of the northern part depends on relatively regular spring floods (Hájek, 2009).

\section{Field and laboratory procedures}

Sampling sites were chosen at stands clear of surface moisture stagnation at the woodland part of the natural reservation Zbytka with alluvial forest Pruno-Fraxinetum (Oberdofer, 1953), approximately $0.5 \mathrm{~km}$ to the south from borehole Lt5 (Fig. 1). Twenty sessile oak trees with relatively similar character (sturdy, without visible signs of trunk and tree-top damage, without fungi attack grown) were chosen and two increment cores were taken from each tree at the height of $1.3 \mathrm{~m}$ above ground.

Tree-ring widths were measured at an accuracy of $0.01 \mathrm{~mm}$ using a measuring device (TimeTable) and the Past4 software (Knibbe, 2004). The synchronization of the raw ring-width series was done using Past 4 software (Knibbe, 2004) using visual comparisons and wellestablished statistical parameters: tBP (Baillie and Pilcher, 1973) and GLK\% (Eckstein and Bauch, 1969). Values of tBP greater than 10.0 and GLK\% values greater than $75 \%$ were considered significant.

\section{Chronology computation}

We produced a residual tree-ring index chronology using the ARSTAN software (Cook and Holmes, 1986). Index chronologies were generated by fitting each series with a negative exponential or linear function, and computing the index by dividing the observed tree-ring values by the expected values (Cook and Kairiukstis, 1990). This served the standardized removal of the age trend (Cook and Peters, 1981; Ford and Brooks, 2003). Autoregressive modelling was performed on each standardized series to remove temporal autocorrelation from the data (Cook, 1985; Cook and Kairiukstis, 1990). The mean residual chronology Q01-ZB were computed from individual indices of each year by means of biweight robust estimation (Cook and Holmes, 1986; Cook and Kairiukstis, 1990) and used in all further analyses. We chose to use the residual index in our analyses to avoid using autocorrelated data which violate the assumptions of the regression analyses (Ford and Brooks, 2003).

\section{Dendroclimatological and dendrohydrological analy- ses}

A climate-growth relationship was investigated using the two different approaches. To understand the relationship between the tree growth and complex actions of climate, the software DENDROCLIM2002 was used that computes the bootstrapped response and correlation functions (Biondi and Waikul, 2004). First, the bootstrapped correlation (CF) and response (RF) function (Cook and Kairiukstis, 1990) were computed for the period 19692008. Correlation was sought between residual chronologies and for monthly climatic data (means air temperature $\left({ }^{\circ} \mathrm{C}\right)$ and total precipitation $(\mathrm{mm})$ from October of the 
previous year's growth to September of the year of growth. This approach ordinarily provides an idea about the average response of trees to the range of climate factors (e.g. Rolland et al., 1998; Solberg et al., 2002; Esper et al., 2002; Wilson et al., 2005a; Wilson et al., 2005b).

This mentioned procedure has not revealed climatic forcing of single extreme years (e.g. Kienast et al., 1987; Schweingruber, 1996). To determine the synchronous extreme growth reaction of trees - pointer years (Lebourgeois, 2007; Schweingruber et al., 1990) using the method of normalization in a moving window (moving window: $5 \mathrm{y}$, thresholds of index value: $\geq 1$ and $\leq-1$ for positive and negative pointer years, respectively; Cropper, 1979). A year was considered to be a pointer year when an extremely narrow or wide tree-ring was detected in at least $50 \%$ of trees per site (Meyer, 1999).

We analysed the influence of water pumping on tree growth using mean residual chronology Q01-ZB and monthly data about level of underground water in monitoring borehole Lt5 from 1968 to 2005. First, we shifted off the influence of temperature in vegetation season (March till September) that mainly affects tree growth. Subsequently, we tested the relationship between the growth and level of underground water by linear models (LM) in program R (www.cran-project.org). We adopted 5 models explaining the tree-growth (no relationship, only temperature influenced, temperature and underground water in linear, quadratic or cubic term influenced) and than we choose the best one according to AIC (Akaike in-formation criterion) value. AIC is a measure of the relative goodness of fit of a statistical model. Finally we tested the significance of the dependence by ANOVA (Analysis of variance).

Meteorological data were obtained from the close meteorological stations, total precipitation from České Meziříčí (approximately $2 \mathrm{~km}$ ) and mean air temperature from Hradec Králové (approximately 20 km).

\section{RESULTS}

\section{Composite of chronology and growth characteristics}

Mean tree ring-width series for 20 trees exhibited no growth anomaly and produced a 159 -y mean chronology spanning the period 1850-2008. The obtained mean chronology had a high statistical quality e.g.: mean sensitivity was 0.22 , low first-order autocorrelation 0.42 , agreement with population chronology 0.95 and mean correlation among trees 0.54 .

Chronology Q01-ZB has been showing different growth trends since 1970s when the waterworks utilization started (Fig. 2). Almost regular decadal fluctuation of tree growth has been coincident with the start of the underground water pumping in 1978.

The analysis of pointer years found 15 years with extremely narrow or wide increments; eight negative and seven positive pointer years (Fig. 3). The occurrence of negative pointer years differed markedly before and after the initiation of pumping underground water. The period 1948-1978 was characterized by frequent strong negative pointer years (1948, 1952, 1956, 1959, 1967 and 1974). A reverse trend was clearly visible during the period 1978-2008. The number of extremely narrow increments declined to two weaker negative pointer years (1996, 2005).

\section{Dendroclimatological and dendrohydrological analy- ses}

Dendroclimatological and dendrohydrological analyses were targeted at the period 1968-2008; climatic and underground water level Lt-5 records exist for these 40 years.

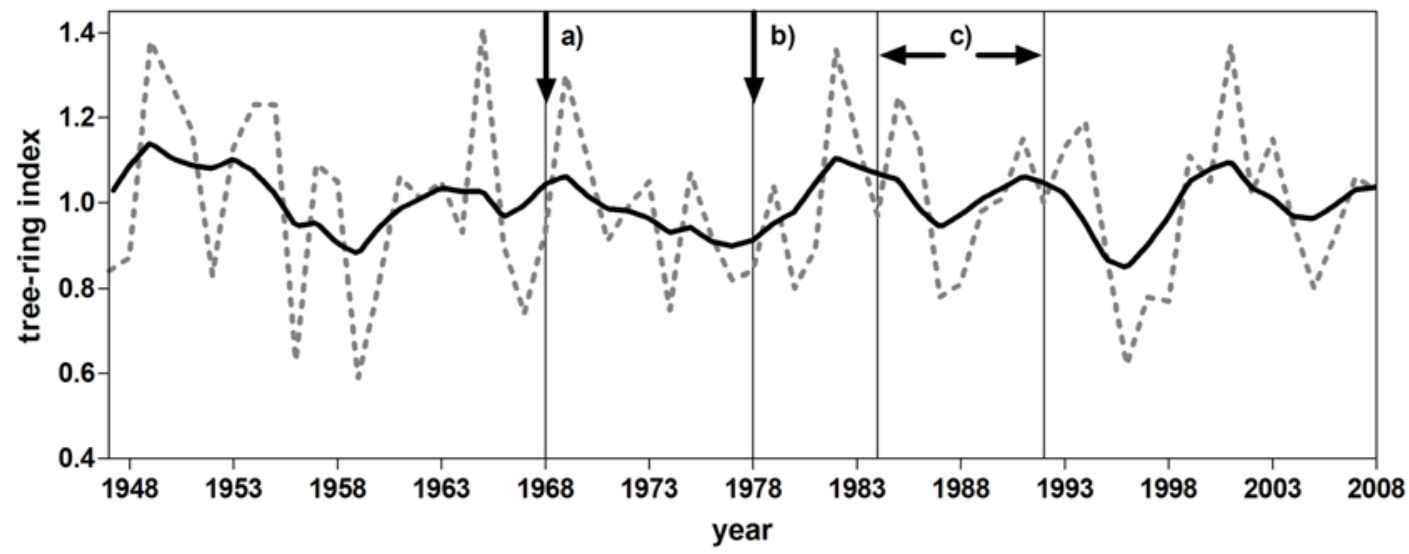

Fig. 2. Residual chronology Q01-ZB (dotted grey line - tree-ring index, black line - 5-year cubic smoothing spline of tree-ring index). a) Start of measuring water table of monitoring borehole Lt5; b) start of waterworks' utilization of the spring area Litá - Mokré, c) period of the strongest pumping artesian water. 




Fig. 3. Extreme growth reactions of trees. The y-axis characterizes the proportion of trees with extremely wide (+) or narrow (-) increments during the same year. Years with synchronous reaction in at least $50 \%$ trees were considered as pointer years (black dots). a) Start of measuring water table of monitoring borehole Lt5; b) start of waterworks' utilization of the spring area Litá - Mokré, c) period of the strongest pumping artesian water.

\section{Influence of climate}

Dendroclimatological analyses mainly revealed a close relationship between temperature and tree growth positive influence of high March, May, July and September temperatures (Fig. 4). The shape of tree-ring curve and mean temperature during vegetation season was almost identical (Fig. 5). Negative correlation was found between the tree growth and high July precipitation and high February temperature/precipitation. Only sporadic reaction to climatic conditions of a year before tree-ring formation was detected - positive influence of high previous September precipitation.

\section{Influence of water pumping}

Influence of fluctuation of underground water on tree growth is related to climate, notably with temperature. The best model of influence on chronology Q01-ZB was



Fig. 4. Climate-growth relationship: significant correlation (columns) and response (dots) functions coefficients $(P<0.05)$ for chronology Q01-ZB, related to mean monthly temperature (black) and precipitation (grey) from October of the previous year's growth $(p)$ to September of the year of growth.

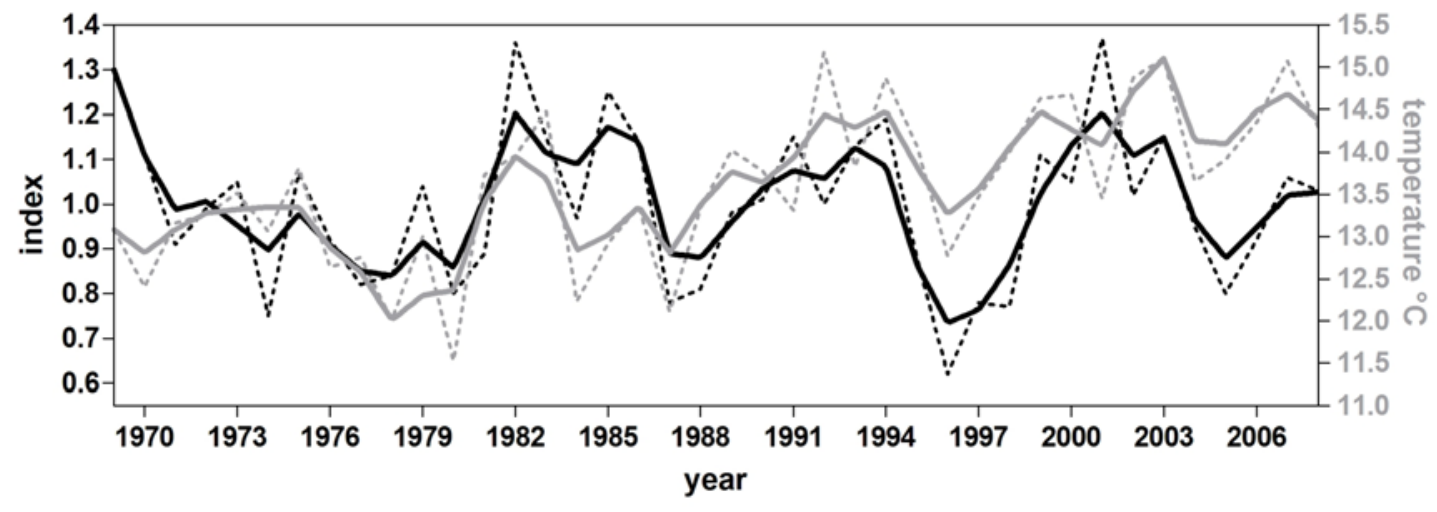

Fig. 5. Correlation between tree-ring index of chronology Q01-ZB (dotted black line, black line - 5-year cubic smoothing spline of tree-ring index) and mean temperature from March to September (dotted grey line, grey line - 5-year cubic smoothing spline of mean temperature). 
created by average temperature and quadratic term of the underground water level (Table 1). The growths of trees decreased with low temperature during growing season together with average underground water level (Fig. 6). Growth depressions concided with high water table of the monitoring borehole Lt-5 to the year 1982 (Fig. 7). The period 1983-1992 of maximum artesian water pumping is expressed by higher tree-ring increments. Pumping reduction of artesian water has been displayed as growth depression since 1993. The recovery tree growth was probably a consequence of 5 year period of higher
Table 1. Models of influence of average temperature (av.temp.) and underground water level (und.wat.) on Q01-ZB. AIC - Akaike information criterion, $d f$ - degrees of freedom, $F-$ test statistics of ANOVA, p-significance.

\begin{tabular}{lcccl}
\hline & df & AIC & F & p \\
\hline Q01-ZB 1 & 2 & 304.5 & & \\
Q01-ZB av.temp. & 3 & 302.6 & 4.8 & 0.036 \\
Q01-ZB av.temp.+und.wat. & 4 & 304.4 & 0.3 & 0.6 \\
Q01-ZB av.temp.+und.wat. $^{2}$ & 5 & 295.7 & 10.8 & 0.002 \\
Q01-ZB av.temp.+und.wat. $^{3}$ & 6 & 297.5 & 0.11 & 0.7 \\
\hline
\end{tabular}

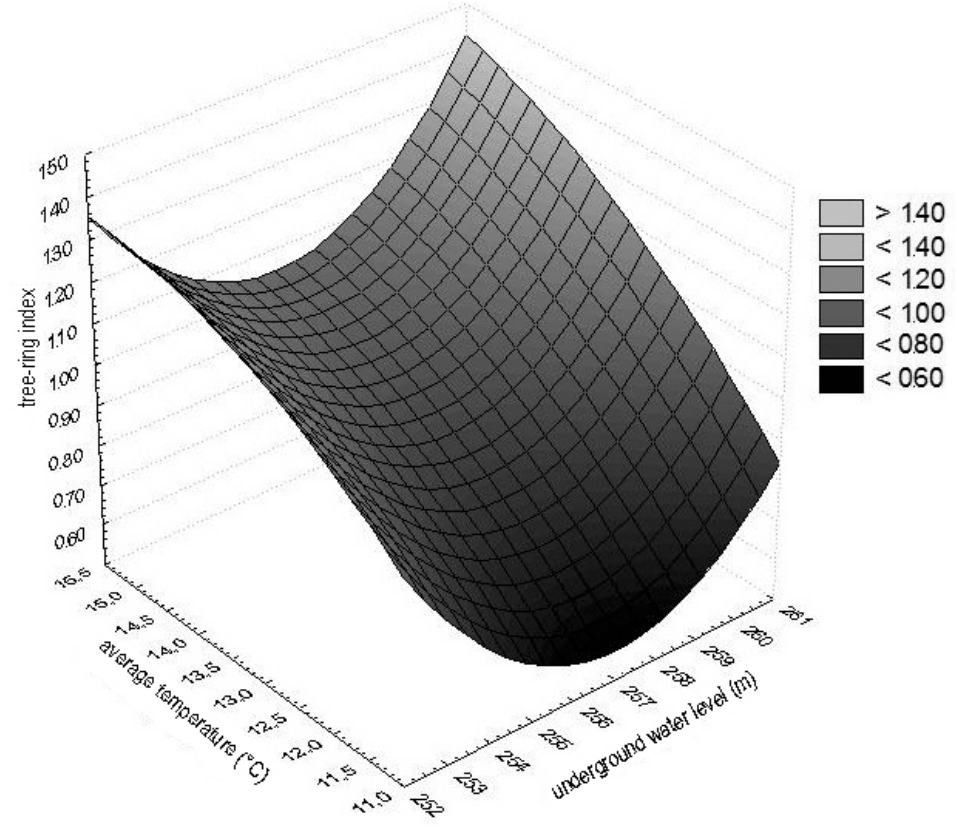

Fig. 6. Relationship between fitted values of tree-ring index of chronology Q02-PR (grey scale reflects range of the values, see legend in the figure), average temperature and underground water level.

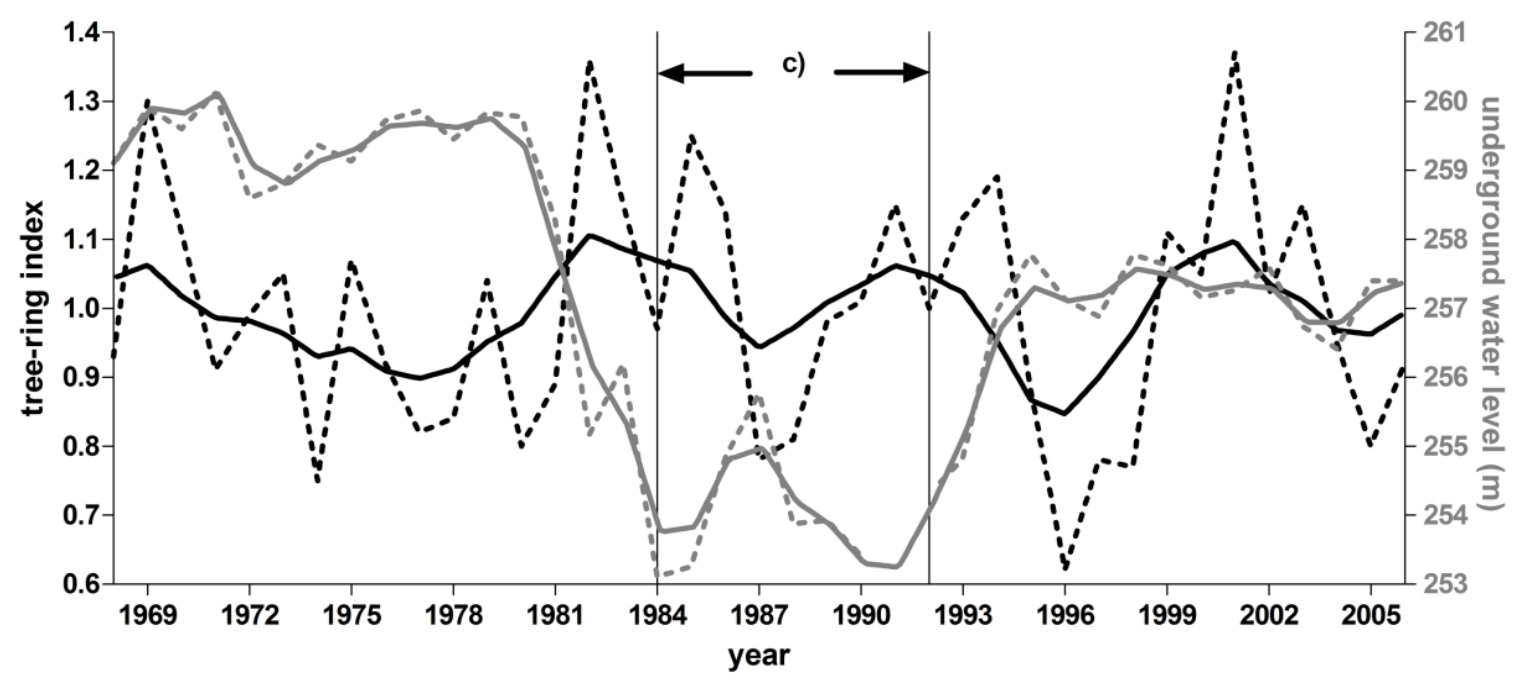

Fig. 7. Tree-ring index of chronology Q01-ZB (dotted black line, black line - 5-year cubic smoothing spline of tree-ring index) and mean year water table of monitoring borehole Lt-5 (dotted grey line, grey line - 5-year cubic smoothing spline of water table). 
temperature and lower precipitation against long term mean during the vegetation season at the end of the 1990s.

\section{DISCUSSION}

\section{Influence of climate}

The amount of precipitation during vegetation season had no positive effect on oak growth in the Zbytka area (Fig. 4). This output was rather surprising, because oaks respond mainly to water balance and drought (Bréda and Badeau, 2008). The growth of oak trees is usually limited by precipitation during the vegetation season and amplifying negative factor is high temperature, which deepen site water deficit across the European continent (e.g. Siwecki and Ufnalski, 1998; Horáček et al., 2003; Lebourgeois et al., 2004; Cedro, 2007; Neuwirth, et al., 2007; Čufar, et al., 2008; Drobyshev, et al., 2008; Friedrichs et al., 2009; Ruseckas, 2006; Andersson, 2009). These studies indicated that oak sensitivity to water stress is especially high during spring and early summer - June and July precipitation are essential controlling factors for oak growth.

Reason of a positive reaction tree-ring increment to high temperature during vegetation season could be caused by sufficient water supply this forest vegetation in Zbytka (Figs. 4, 5). Similar results were obtained by Ruseckas (2006) in Lithuania. Radial increment of the oak stands was positively correlated with the mean air temperatures of March, May, July, August, summer and annual means in the temporarily overmoistured sites on fine or coarse-on-fine textured soils with a shallow water table. Ruseckas (2006) connected the positive growth reaction of the oak stands with the increase in annual temperatures and oak's tolerance to xero-mesophytic conditions. Negative reaction to the high precipitation in July (Fig. 4) can be explained by temporarily overmoisturing of the sites. In very wet years, anoxic stresses may cause growth rates to be suppressed if the root zones become saturated (Stromberg, 2001). A special case was oaks growing in currently extinct natural mire woodlands of NW Europe where growth was apparently negatively correlated to the amount of precipitation during the growth season (Sass-Klaassen and Hanraets, 2006).

The tree ring growth in Zbytka reserve also reacted significantly to climatic conditions before the vegetation season. This is in agreement with the results of previous studies (e.g. Nola, 1996; Drápela and Zach, 1995; Lebourgeois et al., 2004; Cedro, 2007; Drobyshev et al., 2008; Fridrichs at al., 2009; Ruseckas, 2006; Andersson, 2009), wherein the tree ring growth and primarily earlywood with large vessels is influenced by climatic conditions of the previous year, winter temperatures and treering width in the previous year.

The positive influence of high March temperature (Fig. 4) is related to the production of new earlywood for the spring recovery of hydraulic conductivity before leaf expansion (Cruiziat et al., 2002). Carbohydrate storage has a high spring mobilization and is allocated to tree organs before bud burst. The phenology and anatomy pattern of the ring-porous species cause this typical seasonal dynamic of stored nutrients, when about $30 \%$ of the total annual stem increment (mainly earlywood formation) is added before bud burst (e.g. Barbaroux and Bréda, 2002). In general, large diameter vessels were more prone to freezing-induced dysfunction than small vessels (Tyree and Cochard, 1996). The large vessels of earlywood in oaks are very sensitive to embolism caused by frost events and a large part of the previous year's earlywood vessels are embolized by low winter temperatures (Hacke and Kauter, 1996; Cruiziat et al., 2002). High March temperature has also favourable effect on the rooting of the trees owing to the permeability of the subsoil (Becker et al., 1994).

The negative influence of high February temperature (Fig. 4) is apparently discordant with oak ecophysiology, but high February temperature and precipitation could prematurely stimulate production of earlywood and subsequently the vascular tissue could less withstand sudden spells of low temperatures. The resistance of oak trees to low temperatures may increase a high amount of translocation carbohydrates in plant tissues (Drobyshev et al., 2008). Carbohydrate storage (starch and sugars) mainly occurs in autumn and favourable autumn temperature enables more carbohydrates to complete relocation of transportable assimilates from leaves to perennial parts of the tree. This results in more available energy reserves during the following growing season (Andersson, 2009; Drobyshev et al., 2008). Moreover, adequate water saturation during autumn (Fig. 4) prolongs production and accumulation of nutrients, which gives a support to the roots growth at the end of vegetation season, until the soil temperatures become too low (Lebourgeois et al., 2004). Resulting extensive root system provides for higher treering increment next year (Santini et al., 1994).

\section{Influence of water pumping}

The shape of the chronology curve demonstrated more fluctuation after the start of pumping than before, but with less abrupt negative events. Higher proportion of negative pointer years is typical for period before pumping. Widespread growth anomaly occurred only before the start of pumping and after pumping reduction since 1992. The strong pointer years 1956, 1959 and 1996 of oak are expressed in numerous sites across Europe (Neuwirth et al., 2007; Drobyshev et al., 2008; Bréda and Badeau, 2008). The spatial pattern of the pointer year expressions is controlled by sub-regional variation in the expression of weather extremes (Drobyshev et al., 2008).

Decreasing underground water presumably weakens the influence of unfavourable climatic conditions, especially abrupt deviations. Extensive growth depressions could be caused by long-term stresses, such as competition, water regime or changes of climate, while shorter 
growth depressions are more likely to be caused by shortduration stress factors, such as insect defoliations or extreme droughts (Andersson, 2009). Nowadays in wetland oak sites, many old oaks died due to a rising groundwater table (Sass-Klaassen and Hanraets, 2006). Waterlogging caused root damage due to lack of oxygen in the root zone. Also mycorrhizas are very sensitive to changes of the soil hydrology, because prolonged wet conditions cause the die-off (Vasilas et al., 2004).

Underground water table sink is connected with growth release of sampled trees (Fig 7). It corresponds with findings about tree growth reaction to drainage (e.g. Becker et al., 1996; McDonald and Yin, 1999; Linderholm, 1999; Choi et al., 2007; Freléchoux et al., 2000) or generally to drier periods (Sass-Klaassen and Hanraets, 2006). Underground water tables sink generally starts decomposition and release of nutrients.

Many oaks were locally found dying due to increasing wetness at the low parts of Zbytka forests during the 1990 s. Waterlogging was caused by dysfunction of drainage channels, reduction of pumping artesian water and floods (Krahulec in Herrmann, 2005).

Also the study of Vacek and Podrázský in Hermann (1995) detected deceleration of radial increment of trees in the Zbytka alluvial forest since the 1980s. Contrariwise to Krahulec (in Herrmann, 2005) and part of our findings, they related the decrease phenomenon to deficit of water in alluvial forest ecosystem due to drainage and water pumping, aside from natural climatic fluctuation.

Interestingly, the linear model analyses (Fig. 6) showed that the growth reaction of oak has not simple causality between temperature and underground water level, what indicated depicted curves chronology Q01-ZB and mean underground water level (Fig. 7) or mean temperature (Fig. 4). The radial increments reacted positively to the combination of high temperature during vegetation season and low or the contrary high depth of underground water level.

This contradiction can be caused by: (i) trees, especially oaks in modern wetland woods favourably germinate on rather higher and thus drier spots which makes them less susceptible to a temporary high groundwater level or flooding and could provide better chances to survive wet periods (Sass-Klaassen, 2004; Sass-Klaassen and Hanraets, 2006); (ii) inundation represented by spring floods in Zbytka area, changing water chemistry, particularly the concentration of nutrients and dissolved oxygen (Davidson et al. 2006). Additionally floods are a rich source of nutrients (Stromberg, 2001); (iii) climate changes could be a driving factor of earlier start of the growth period; oak stands become more sensitive to the soil moisture regime (Ruseckas, 2006) and proved inconsistent growth reaction to fluctuation of underground water level.

\section{CONCLUSION}

Although there is no direct relationship between tree growth and fluctuation of underground water level, the study indicates the usability of dendrochronology as one of the tools to evaluate human impact in this area. Our results also suggest that dendrochronological data may also be useful in historical ground water modelling studies.

\section{ACKNOWLEDGEMENTS}

The authors thank intuitions providing climatological and hydrological data, English speaking friends for improving our English. This research was supported by Ministry of Education of the Czech Republic grant MSM6007665801.

\section{REFERENCES}

Andersson M, 2009. Oak (Quercus robur L.) mortality in south-eastern Sweden: influence of weather and environmental variables. Master Thesis, Department of Physics, Chemistry and Biology; Linköpings universitet SE-581 83 Linköping, Sweden.

Baillie MGL and Pilcher JR, 1973. A simple cross-dating program for tree-ring research. Tree-Ring Bulletin 33: 7-14.

Barbaroux C and Bréda N, 2002. Contrasting distribution and seasonal dynamics of carbohydrate reserves in stem wood of adult ringporous sessile oak and diffuse-porous beech trees. Tree Physiology 22: 1201-1210, DOI 10.1093/treephys/22.17.1201.

Becker M, Nieminen T M and Gérémia F, 1994. Short-term variations and long-term changes in oak productivity in northeastern France. The role of climate and atmospheric $\mathrm{CO}_{2}$. Annales des Sciences forestières 51(5): 477-492, DOI 10.1051/forest:19940504.

Becker M, Lévy G and Lefevre Y, 1996. Radial growth of mature pedunculate and sessile oaks in response to drainage, fertilization and weeding on acid pseudogley soils. In: Dreyer E and Aussenac $\mathrm{G}$, eds., Ecology and Physiology of Oaks in a Changing Environment. Annales des Sciences forestières 53(2-3): 585-594, DOI 10.1051/forest: 19960237 .

Biondi $\mathrm{F}$ and Waikul K, 2004. DENDROCLIM2002: A C++ program for statistical calibration of climate signals in tree-ring chronologies. Computers and Geosciences 30(3): 303-311, DOI 10.1016/j.cageo.2003.11.004.

Bréda $\mathrm{N}$ and Badeau V, 2008. Forest tree responses to extreme drought and some biotic events: Towards a selection according to hazard tolerance? Comptes Rendus Geoscience 340(9-10): 651-662, DOI 10.1016/j.crte.2008.08.003.

Bušek O, 2006. EVL Zbytka odběr podzemnich vod - Posouzení významnosti vlivu záméru na lokalitu soustavy NATURA 2000 (EVL Zbytka andeground water consumption - Judgement influence on the locality Europien Natura 2000 network): 20pp (in Czech).

Cedro A, 2007. Tree-ring chronologies of downy oak (Quercus pubescens), pedunculate oak ( $Q$-robur) and sessile oak ( $Q$-petraea $)$ in the Bielinek Nature Reserve: Comparison of the climatic determinants of tree-ring width. Geochronometria 26: 39-45, DOI 10.2478/v10003-007-0005-2.

Choi W-J, Chang SX, Bhatti JS, 2007. Drainage affects tree growth and $\mathrm{C}$ and $\mathrm{N}$ dynamics in a minerotrophic peatland. Ecology 88(2): 443-453, DOI 10.1890/0012 9658(2007)88[443:DATGAC]2.0.CO;2.

Cook ER, 1985. A time series analysis approach to tree-ring standardization. Ph.D. Watershed Management thesis-University of Arizona, Tucson.

Cook ER and Holmes RL, 1986. User manual for program Arstan. In: Holmes R L, Adams R K and Fritts HC, eds., Tree-Ring Chronol- 
ogies of western North America: California, eastern Oregon and northern Great Basin. Chronology Series VI. Laboratory of TreeRing Research, The university of Arizona, Tuscon: 50-60.

Cook ER and Kairiukstis LA, 1990. Methods of Dendrochronology, Applications in the Environmental Sciences. Kluwer Academic Publischers, Dodrecht, Boston, London: 394pp.

Cook ER and Peters K, 1981. The smoothing spline: a new approach to standardizing forest interior tree-ring width series for dendroclimatic studies. Tree-Ring Bulletin 41: 45-53.

Cruiziat P, Cochard H and Améglio T, 2002. Hydraulic architecture of trees: main concepts and results. Annals of forest science 59(7): 723-752, DOI 10.1051/forest:2002060.

Cropper JP, 1979. Tree-ring skeleton plotting by computer. Tree-Ring Bulletin 39: 47-60.

Čufar K, De Luis M, Eckstein D and Kajfež-Bogataj L, 2008. Reconstructing dry and wet summers in SE Slovenia from oak tree-ring series. International Journal of Biometeorology 52 (7): 607-615, DOI 10.1007/s00484-008-0153-8.

Dale VH, 1997. The relationship between land-use change and climate change. Ecological Applications 7(3): 753-769, DOI 10.1890/1051-0761(1997)007[0753:TRBLUC]2.0.CO;2.

Dang QL and Lieffers VJ, 1989. Assessment of patterns of response of tree ring growth of black spruce following peatland drainage. $\mathrm{Ca}$ nadian Journal of Forest Research 19(7): 924-929, DOI 10.1139/x89-140.

Davidson GR, Laine CB, Galicki SJ and Threlkeld ST, 2006. Root-Zone Hydrology: Why Bald Cypress in Flooded Wetlands Grow More When it Rains. Tree-Ring Research 62(1): 3-12.

Douda J, Čejková A, Douda K and Kochánková J, 2009. Developmnet of alder carr after abandonment of wetland grasslands during the last 70 years. Annals of forest science 66(7): 712, DOI $10.1051 /$ forest $/ 2009065$

Drápela K and Zach J, 1995. Dendrometrie (Dendrochronologie). MZLU, Brno (in Czech): 149pp (in Czech).

Drobyshev I, Niklasson M, Eggertsson O, Linderson H and Sonesson K, 2008. Influence of annual weather on growth of pedunculate oak in southern Sweden. Annals of forest science 65: 512, DOI 10.1051/forest:2008033.

Eckstein D and Bauch J, 1969. Beitrag zu Rationalisierung eines dendrochronologischen Verfahrens und zu Analyse seiner Aussagesicherheit. Forstwissenschaftliches Centralblatt 88: 230-250.

Esper J, Cook ER and Schweingruber FH, 2002. Low-frequency signals in long tree-ring chronologies for reconstructing past temperature variability. Science 295: 2250-2253, DOI: 10.1126/science.1066208.

Faltysová H, Mackovčin P, Sedláček M and al., 2002. Královéhradecko (Hradec Králové region). In: Mackovčin P and Sedláček M, eds., Chránéná území ČR, svazek V. AOPK ČR a EkoCentrum Brno, Praha (in Czech).

Ford CR and Brooks JR, 2003. Hydrological and climatic responses of Pinus elliottii var. densa in mesic pine flatwoods Florida, USA. Annals of Forest Science 60(5): 385-392, DOI 10.1051/forest:2003030.

Freléchoux F, Buttler A, Schweingruber FH and Gobat JM, 2000. Stand structure, invasion, and growth dynamics of bog pine (Pinus uncinata var. rotundata) in relation to peat cutting and drainage in the Jura Mountains, Switzerland. Canadian Journal of Forest Research 30(7): 1114-1126, DOI 10.1139/x00-039.

Friedrichs D, Büntgen U, Esper J, Frank D, Neuwirth B and Löffler J, 2009. Complex climate controls on 20th Century oak growth in Central-West Germany. Tree Physiology 29(1): 39-51, DOI 10.1093/treephys/tpn003.

Hacke U and Sauter JJ, 1996. Xylem dysfunction during winter and recovery of hydraulic conductivity in diffuse-porous and ringporous trees. Oecologia 105(4): 435-439, DOI 10.1007/BF00330005.

Hájek A, 2009. Květena př́rodni rezervace Zbytka u Českého meziřicív severovýchodních Ćechách ve vztahu k historickému vývoji locality (Flora of the Zbytka Nature Reserve near České Meziříćí in northeastern Bohemia in relation to the historical development of the locality), Libri, občanské sdružení Dobré: 98pp (in Czech).
Hermann Z, ed., 1995. Litá-Zbytka. Př́rodní rezervace. Hydrogeologické a biologické zhodnoceni (Litá-Zbytka. Nature reservation. Hydrogeological and biological judgment). MS Aquatest, a.s. Praha: 93pp (in Czech).

Hermann Z, ed., 2005. Litá - monitoring 1999 - 2004. MS Aquatest, a.s. Praha (in Czech)

Horáček P, Šlezingerová J and Gandelová L, 2003. Analysis of cambial activity and formation of wood in Quercus robur L. under conditions of a floodplain forest. Journal of Forest Science 49(9): 412418.

Hrkal Z, 1998. Optimalizace ochrany a využiti podzemnich vod severní části hydrogeologického rajónu 422 - Podorlická křída (Opočnská kotlina) ve vztahu $\mathrm{k}$ ostatním složkám životního prostředí a ochrany prírody (Optimalization of conservation underground water utilization in the northern part of hydrogeological region 422 Podorlická kř́́da (Opočenská kotlina) in conection to environment and nature conservation): $139 \mathrm{pp}$. et append $\mathrm{ms}$ (in Czech).

Kienast F, Schweingruber FH, Bräker OL and Schär E, 1987. Tree-ring studies on conifers along ecological gradients and the potential of single-year analyses. Canadian Journal of Forest Research 17(7): 683-696, DOI 10.1139/x87-111.

Knibbe B, 2004. Past4 - Personal Analysis System for Treering Research Version 4, Instruction Manual. SCIEM/Bernhard Knibbe, Wien: $101 \mathrm{pp}$

Kopecký K, 1960. Fytocenologická studie slatinných luk v severovýchodních Čechách (Vegetation study of fen meadows in the Northeastern Bohemia). Rozpravy Československé akademie Věd, Praha, ser math-natur. 70(4): 1-64 (in Czech).

Krahulec F, 1995. Luční ekosystem (Grassland ecosystem). In: Hermann Z, ed., Litá-Zbytka. Př́rodní rezervace. Hydrogeologické a biologické zhodnoceni (Litá-Zbytka. Nature reservation. Hydrogeological and biological judgment). MS Aquatest, a.s. Praha: 93pp (in Czech).

Krčan K and Kopecký K, 1959. Květena okolí Nového města nad Metují (Flora of Nové město nad Metují surroundings). Preslia, Praha, 31: 52-77 (in Czech).

Kroupa J, 1986. Historie cukrovaru v Českém Meziřící (History of sugar rafinery in České Meziříčí. In: Bouza E, Čížek J et al., eds., České Meziřičí. Sbornik dějin a součastnosti střediskové obce (Aniversary volume of history and nowadays of central village). Místní národní výbor České Meziříčí: 33-39 (in Czech).

Lageard JGA and Drew IB, 2008. Hydrogeomorphic control on tree growth responses in the Elton area of the Cheshire Saltfield, UK. Geomorphology $\quad 95(3-4): \quad 158-171, \quad$ DOI 10.1016/j.geomorph.2007.05.017.

Lebourgeois F, Cousseau G and Ducos Y, 2004. Climate-tree-growth relationships of Quercus petraea Mill. stand in the Forest of Bercé ("Futaie des Clos", Sarthe, France). Annals of Forest Science 61: 361-372, DOI 10.1051/forest:2004029.

Lebourgeois F, 2007. Climatic signal in annual growth variation of silver fir (Abies alba Mill.) and spruce (Picea abies Karst.) from the French Permanent Plot Network (RENECOFOR). Annals of Forest Science 64: 333-343, DOI 10.1051/forest:2007010.

Linderholm HW, 1999. Climatic and anthropogenic influences on radial growth of Scots pine at Hanvedsmossen, a raised peat bog, in southcentral Sweden. Geografiska Annaler 81A(1): 75-86.

Linderholm HW and Leine M, 2004. Assessing twentieth Century treecover changes on a southern Swedish peatland combining dendrochronological and remote sensing methods. Wetlands 24: 357-363.

McDonald SE and Yin F, 1999. Factors influencing size inequality in peatland black spruce and tamarack: evidence from post drainage release growth. Journal of Ecology 87(3): 404-412, DOI 10.1046/j.1365-2745.1999.00370.x.

Meyer FD, 1999. Pointer year analysis in dendroecology: A comparison of methods. Dendrochronologia 16-17: 193-204.

Mitsch W J and Gosselink J G, 2007. Wetlands. John Wiley and Sons, Hoboken, New Jersey, USA: 295pp.

Nola P, 1996. Climatic signal in earlywood and latewood of deciduous oaks from northern Italy. In: Dean J S, Meko DM and Swetnam TW, eds., Tree Rings, Environment, and Humanity. Radiocarbon: 149-258. 
Neuwirth B, Schweingruber FH and Winiger M, 2007. Spatial patterns of central European pointer years from 1901 to 1971. Dendrochronologia 24: 79-89, DOI 10.1016/j.dendro.2006.05.004.

Oberdorfer E, 1953. Der europäischen Auenwald. Beitrage zur Naturkundlichen Forschung in Südwest-Deutschlland 12: 23-70.

Prokeš K and Válek B, 1944. Př́spěvky ke květeně severovýchodních Čech II (Report of flora northeastern Bohemia II). Př́roda, Brno 36: 328-331 (in Czech).

Prokeš K and Válek B, 1946. Př́íspěvky ke květeně severovýchodních Čech IV (Report of flora northeastern Bohemia IV). Príroda, Brno 38: 159-161 (in Czech).

Rodríguez-González MG, Stella JC, Campelo F, Ferreira MT and Albuquerque A, 2010. Subsidy or stress? Tree structure and growth in wetland forests along a hydrological gradient in Southern Europe. Forest Ecology and Management 259(10): 2015-2025, DOI 10.1016/j.foreco.2010.02.012.

Rohlena J and Dostál J, 1936. Př́spěveky k floristickému výzkumu Čech XII (Report of flora Bohemia investigation XII). Časopis Národního muzea, Praha, sect. nature. 110: 22-45 (in Czech).

Rohlena J and Dostál J, 1937-1938. Př́spěveky k floristickému výzkumu Čech XIII (Report of flora Bohemia investigation XII). Časopis Národního muzea, Praha, sect. nature. 111: 163-176 and 112: 29-32 (in Czech).

Rolland C, Petitcolas V, Michalet R, 1998. Changes in radial tree growth for Picea abies, Larix decidua, Pinus cembra and Pinus uncinata near the alpine timberline since 1750. Trees 13: 40-53, DOI 10.1007/PL00009736.

Růžička J, red, 2006. Odběry podzemnich vod z prameniště Litá a Mokré v letech 2007 - 2015 pro zásobováni obyvatel pitnou vodou - Dokumentace (dle prílohy č.4 zákona č.100/2001 Sb.) (Anderground water consumption from the spring area Litá a Mokré 2007 - 2015 for potable water supplying of inhabitants). G-servis Praha spol.s r.o: 82pp (in Czech).

Ruseckas J, 2006. Impact of climatic fluctuations on radial increment of English oak (Quercus robur L.). Ekologia 1: 16-24.

Santini A, Bottacci A and Gellini R, 1994. Preliminary dendroecological survey on pedunculate oak (Quercus robur L.) stands in Tuscany (Italy). Annales des Sciences forestières 51: 1-10, DOI 10.1051/forest: 19940101 .

Sass-Klaassen U, 2004. Exploring oaks in modern wetland woods in Europe to trace the climate signal in tree-ring series of sub-fossil bog oaks. In: Jansma $\mathrm{E}$ and Gaertner $\mathrm{H}$, eds. TRACE, Tree Rings in Archeology, Climatology and Ecology 2: 67-72.

Sass-Klaassen U and Hanraets E, 2006. Woodlands of the past - The excavation of wetland woods at Zwotte-Stadshagen (the Nether lands): Growth pattern and population dynamics of oak and ash. Netherlands Journal of Geosciences-Geologie en Mijnbouw 85: 61-71.

Schweingruber FH, 1996. Tree Rings and Environment Dendroecology. Birmensdorf, Swiss Federal Institute for Forest, Snow and Landscape Research. Berne, Stuttgart, Vienna, Haupt: 609pp.

Schweingruber FH, Eckstein D, Serre-Bachet F and Bräker OU, 1990. Identification, presentation and interpretation of event years and pointer years in dendrochronology. Dendrochronologia 8: 9-38.

Siwecki R and Ufnalski K, 1998. Review of oak stand decline with speciál reference to the role of drought in Poland. European Journal of Forest Pathology 28(2): 99-112, DOI 10.1111/j.14390329.1998.tb01171.x.

Solberg BO, Hofgaard A and Hytteborn H, 2002. Shifts in radial growth responses of coastal Picea abies induced by climatic change during the 20th Century, central Norway. Ecoscience 9(1): 79-88.

Stromberg JC, 2001. Influence of stream flow regime and temperature on growth rate of the riparian tree, Platanus wrightii, in Arizona. Freshwater Biology 46(2): 227-239, DOI 10.1046/j.13652427.2001.00651.x.

Tolasz R, Míková T and Valeriánová A, 2007. Climate atlas of Czechia, ČHMÚ, Praha \& UP, Olomouc: 256 pp.

Tyree MT and Cochard H, 1996. Summer and winter embolism in oak: impact on water relations. Annales des Sciences Forestières 53 (23): $173-180$.

Uhlík J, ed., 2006. Jímaci územi Litá, prírodni rezervace Zbytka. Hydraulické a hydrologické hodnoceni ovlivněni odběru při variantách institutu minimální hladiny na vrtu Lt-5 (Spring area Litá, nature reservation Zbytka. Hydraulical and hydrogeological judgment of institut minimum water level in monitoring bore hole Lt-5 on water uptake). Progeo s.r.o., Ms., depon in Královéhradecká provozní a.s., Hradec Králové (in Czech).

Vasilas B, Vasilas L, Thompson J, Rizzo A, Fuhrmann J, Evans T, Pesek J and Kunklea K, 2004. Ectomycorrhizal mantles as indicators of hydrology for jurisdictional wetland determinations. Wetlands 24: 784-795.

Wilson RJS, Luckman BH and Esper J, 2005a. A 500 year dendroclimatic reconstruction of spring-summer precipitation from the lower Bavarian Forest region, Germany. International Journal of Climatology 25(5): 611-630, DOI 10.1002/joc.1150.

Wilson R, Frank D, Topham J, Nicolussi K and Esper J, 2005b. Spatial reconstruction of summer temperatures in Central Europe for the last 500 years using annually resolved proxy records: probléme and opportunities. Boreas 34(4): 490-497, DOI 10.1080/03009480500231351. 